\title{
Programy postępowania $z$ więźniami jako podstawa resocjalizacji oraz przestrzegania ich praw
}

\author{
KEY WORDS \\ treatment programs, \\ prisoner, \\ social rehabilitation, \\ rights of prisoners, \\ duties of prisoners, \\ prison sentence
}

\begin{abstract}
Jůzl Miloslav, Programy postępowania z więźniami jako podstawa resocjalizacji oraz przestrzegania ich praw [Treatment Programs as a Platform for Social Rehabilitation and Respecting the Rights of Prisoners]. Kultura - Społeczeństwo - Edukacja nr 1 (3) 2013, Poznań 2013, pp. 115-133, Adam Mickiewicz University Press. ISBN 978-83-232-ISBN 978-83-232-2631-4. ISSN 2300-0422

The aim of this article is to introduce and explain the core of social rehabilitation of prisoners which lies in creation and effect of treatment as a necessary prerequisite for their successful return to civic society and as the main factor of permanent humanization of our prison system in the context of respecting the rights and duties of prisoners.
\end{abstract}

\section{Wstęp}

Na początku 2013 roku prezydent Republiki Czeskiej ogłosił amnestię na szeroką skalę. Wywołała ona polemikę i dyskusję nie tylko w kręgach politycznych, lecz głównie wśród społeczeństwa. Towarzyszy im fala żądań rewizji decyzji głowy państwa przede wszystkim odnośnie tej części, która poszła na rękę oszustom, tak zwanych "tunelarzom”. Ich sprawy sądowe toczą się od wielu lat, doszło do bezpowrotnej utraty około 4,5 miliardów koron na szkodę obywateli i państwa. Ten fakt stanowi główny powód niezadowolenia społeczeństwa czeskiego $\mathrm{z}$ amnestii. Kolejne ujemne strony przedstawia wzmożona działalność przestępcza zwolnionych; niestety, część z nich powróciła wkrótce do więzień. Osoby objęte amnestią dokonały już kilku najcięższych zbrodni, wskutek których zginęly niewinne ofiary.

Należy jednak wspomnieć również dodatnie strony amnestii na szeroką skalę. W nadmiernie przepełnionych zakładach karnych dochodziło do różnych nega- 
tywnych zjawisk, których wynikiem były wielorakie formy protestów. Dzięki zwolnieniu znacznej liczby osób rozładowało się napięcie w czeskich zakładach karnych, podobnie jak dwadzieścia trzy lata temu, kiedy amnestię w jeszcze szerszym zakresie podpisał ówczesny prezydent Republiki Czeskiej Václav Havel (1936-2011). Pomijając to wszystko, Więzienna Służba Republiki Czeskiej zaoszczędzi na dziennych kosztach obsługi więzień około 6 milionów koron, co przedstawia w skali rocznej poważną pozycję - 2,2 miliardy koron czeskich.

W tym miejscu prezentujemy sytuację, jaka ukształtowała się na początku lat dziewięćdziesiątych wskutek długofalowego nierozwiązywania problemów w angielskich zakładach karnych. Analizę więziennictwa przeprowadził członek Najwyższego Sądu Wielkiej Brytanii Woolf oraz sędzia Stephen Tumim. Ich wnioski obowiązują do dzisiaj i mogłyby zostać wykorzystane przez służby więzienne innych krajów europejskich.

\section{Dwanaście głównych tez Woolfa}

Przedstawiciel Sądu Najwyższego lord Harry Kenneth Woolf oraz sędzia Stephen Tumim zaproponowali dwanaście głównych zmian, które, ich zdaniem, należałoby przeprowadzić. Zostały one zapisane w artykułach nr 1.167 oraz 15.5 raportu o stanie więziennictwa.

Oto lista postulatów:

1) Doprowadzenie do ściślejszej współpracy pomiędzy pojedynczymi ogniwami systemu prawa karnego. W tym celu należy powołać forum narodowe oraz komitety lokalne.

2) Bardziej zdecydowane kierowanie służbą więzienną przez dyrektora naczelnego, który powinien śledzić na co dzień pracę podległej mu instytucji. Celem realizacji niniejszego punktu należy ujawnić umowę zawartą pomiędzy Radą Ministrów a dyrektorem naczelnym, odpowiedzialnym za wykonywanie swoich obowiązków. Powinien on informować społeczeństwo i odpowiadać na pytania dotyczące bieżącej pracy służby więziennej.

3) Zwiększenie odpowiedzialności dyrektorów pojedynczych placówek.

4) Zaakcentowanie roli funkcjonariuszy więziennych w stopniu oficerskim.

5) Uzgodnienia oraz umowa $z$ każdym więźniem, zawierająca dane na temat tego, czego może się spodziewać; jego odpowiedzialność w zakładzie karnym, w którym się znajduje.

6) Stworzenie narodowego systemu uchwalonych urzędowo zasad, które powinny być stopniowo przyjmowane w każdym zakładzie karnym.

7) Nowa zasada więzienia, zgodnie z którą w każdym zakładzie karnym nie powinno się znajdować więcej odsiadujących wyrok, aniżeli pozwalają na to ist- 
niejące warunki. W przypadku wyjątkowego naruszenia wspomnianych przepisów należy informować o tym fakcie parlament.

8) Opracowanie przez ministrów harmonogramu podwyższenia poziomu warunków higienicznych dla wszystkich więzionych, co powinno nastąpić w jak najszybszym okresie, najpóźniej do lutego 1996 roku.

9) Poprawienie kontaktów uwięzionych z rodziną i społeczeństwem poprzez częstsze wizyty i urlopy oraz umieszczanie ich w zakładach karnych jak najbliżej miejsca zamieszkania.

10) Podział zakładów karnych na mniejsze jednostki, poprawa organizacji oraz podwyższenie ich bezpieczeństwa.

11) Indywidualne określanie celu, warunków izolacji oraz ogólnie niższa kategoria bezpieczeństwa w aresztach śledczych.

12) Zwiększenie stopnia sprawiedliwości w więzieniach, informowanie więźniów o powodach wprowadzenia decyzji mających istotne, chociaż niekorzystne skutki dla ich życia. Informowanie o załatwianiu skarg oraz spowodowanie, by gros spraw dyscyplinarnych mogło być rozpatrywanych przez dyrektora; nadanie decydującej rangi komitetom wizytującym. Możliwość ostatecznego odwołania się do niezależnego arbitra rozpatrującego skargi.

\section{Raport Woolfa - podsumowanie głównych wyników analiz oraz propozycje ustalenia przyczyn rewolt i protestów więźniów}

Bunt w zakładzie karnym w Strangeways w kwietniu 1990 roku, protesty i zamieszki, które wystąpiły w tym samym czasie w wielu kolejnych więzieniach, należały do najpoważniejszych w historii brytyjskiego wymiaru sprawiedliwości. 6 kwietnia 1990 roku ówczesny minister spraw wewnętrznych David Waddington upoważnił członka Sądu Najwyższego Woolfa do ustalenia ich przyczyn. W lipcu 1990 roku dokooptowano do zespołu analizującego sytuację sędziego Stephena Tumima, głównego inspektora więziennego. Miał on pomóc przy ustalaniu szerszego kontekstu niepokojów w więzieniach.

31 stycznia 1991 roku sędzia Woolf przekazał sześćsetstronicowy raport na ręce nowego ministra spraw wewnętrznych Kennetha Bakera. Analiza zdarzeń w Strangeways, dokładny opis warunków w brytyjskich zakładach karnych oraz sama ocena sytuacji przedstawiają najbardziej znaczącą analizę systemu karnego w przeciągu ostatnich stu lat (Raport Woolfa, 1996). 


\section{Cel, zadania i zasady odbywania kary pozbawienia wolności}

Podstawową ideę wyjściową kary pozbawienia wolności stanowi przekonanie, że ludzie, którym udowodniono popełnienie czynu karalnego, powinni zostać ukarani. W przypadku poważniejszej zbrodni stosowana jest kara pozbawienia wolności, w zależności od stopnia przewinienia nawet na okres kilku lat, czy do końca życia.

Skuteczność kary pozbawienia wolności wiąże się z jej następującymi funkcjami: ukaranie za popełniony czyn, rozumiane przez stulecia w taki sam sposób, odizolowanie przestępców od społeczeństwa, resocjalizacja, będąca procesem prowadzącym do zmian zachowania jednostki, mająca na celu umożliwienie jej ponownego funkcjonowania w społeczeństwie ludzkim. Resocjalizacja ma miejsce zwłaszcza w społeczeństwach postmodernistycznych.

Celem kary pozbawienia wolności jest zapobieganie popełnianiu kolejnych czynów karalnych. Należy przy tym zwrócić szczególną uwagę na: powstrzymanie zjawiska desocjalizacji (pryzonizacji), umożliwienie rozwoju jednostki drogą wychowania oraz kształcenia, powrót osadzonego do cywilizowanego społeczeństwa tak, by zrezygnował z działań przestępczych, by zarabiał na życie swoje i rodziny uczciwą pracą, by zachowywał się jak dostosowany społecznie obywatel. Efektywność kary pozbawienia wolności wspierają następujące zasady: przestrzeganie praworządności, humanizacja, depryzonizacja, demokratyczne podejście (Inciardi, 1994).

\section{Resocjalizacja}

Aby zrozumieć znaczenie programów postępowania z więźniami, należy najpierw wyjaśnić pojęcia: resocjalizacja oraz resocjalizacja twórcza. Resocjalizacja sama w sobie rozumiana jest jako proces ponownej socjalizacji, powrotu do społeczeństwa. Taka sytuacja konieczna jest w przypadku jednostki, która ma odnaleźć się wśród normalnych ludzi, powinna więc zostać uspołeczniona. Pojęcie socjalizacji występuje w dyscyplinach: pedagogika specjalna oraz socjalna, praca społeczna, penologia, penitencjarystyka. Wyróżniamy dwie kategorie resocjalizacji: naturalną w szerszym rozumieniu, która przebiega podobnie jak socjalizacja jednost$\mathrm{ki}$ w naturalnych warunkach cywilnych i w środowisku rodzinnym, szkolnym, w społeczeństwie, oraz specyficzną, mającą miejsce właśnie w murach więziennych (Jůzl, 2012).

\section{Resocjalizacja twórcza}

Do ambicji pedagogiki resocjalizacyjnej należy modyfikowanie parametrów jednostki oraz eliminowanie problematycznych, szkodliwych lub patologicznych elementów (dotyczy zarówno jednostki, jak też całego społeczeństwa). Z punktu 
widzenia pragmatycznego resocjalizacja przedstawia metodyczny proces przebudowywania rzeczywistości.

Do części składowych pedagogiki resocjalizacyjnej należy także prewencja społeczna, będąca nauką zajmującą się jednostkami i grupami społecznymi. Pedagogikę resocjalizacyjną cechuje interdyscyplinarny charakter. Oznacza to, że posługuje się ona diagnostyką oraz korzysta z niektórych ogólnych metod pracy z klientem, typowych dla pracy społecznej. Poza tym wchodzi w zakres dyscyplin prawnych, zwłaszcza penologii i kryminologii. Następnie przejmuje elementy andragogiki oraz pedagogiki społecznej.

Pedagogika resocjalizacyjna ma równocześnie charakter biodromalny - towarzyszy człowiekowi podczas całej drogi życiowej.

\section{Cele pedagogiki resocjalizacyjnej:}

1) kreatywne (kształtowanie poglądów, zainteresowań itp.),

2) optymalizujące (wzmocnienie i rozbudowanie uczuciowości, zaangażowania),

3) minimalizujące (redukowanie agresji, minimalizowanie poczucia strachu itd.),

4) korekcyjne (przebudowa, zmiana stanowiska i zdania).

Metody i techniki oddziaływania resocjalizacyjnego:

1) bezpośrednie działanie pedagogiczne,

2) pośrednie działanie pedagogiczne,

3) metoda samorządnego wychowywania jednostek,

4) przekonywanie jako metoda pracy resocjalizacyjnej,

5) metoda pozytywnych przykładów,

6) metody sytuacyjne,

7) psychodrama jako metoda oddziaływania resocjalizacyjnego.

Resocjalizacja twórcza różni się od klasycznej pedagogiki resocjalizacyjnej wieloma cechami:

1) rozwija potencjał ludzki, w odróżnieniu od zwykłej korekcji socjalnych i indywidualnych potencjałów jednostki;

2) niedostosowanie społeczne prezentuje jako socjalizację deficytową tożsamości, a nie tylko jako dewiacyjne stanowisko jednostki;

3) jej celem jest wytworzenie nowych parametrów tożsamości wychowywanego, a nie tylko korekcyjna zmiana przekonań i poglądów, preferowanych wartości, zachowania, roli społecznej;

4) środek do osiągnięcia celu stanowi rozwój jednostki, a nie tylko zamiana ujemnych form postępowania na inne poprzez korekcje i modyfikacje psychiczne.

W przypadku resocjalizacji twórczej, prowadzącej do wytyczonych wyżej celów, dominuje metoda osiągania ich za pośrednictwem trenowania autoprezentacji jednostki przez wizualizowane parametry tożsamości. Chodzi o metodyczne specyfiki socjalizacji twórczej, którą można by charakteryzować przez pojęcia:

Twórczość - Resocjalizacja - Tożsamość. 


\section{Metody socjalizacji twórczej:}

1) metoda teatru resocjalizacyjnego - teatr życia codziennego,

2) metoda resocjalizacyjna wykorzystująca aktywności sportowe,

3) terapia dramaturgiczna - prezentacja dzieła wytworzonego,

4) muzykoterapia, muzyka, występy,

5) terapia drogą aktywności plastycznych rysunki, obrazy, modelowanie,

6) psychodrama oraz socjodrama (Mühlpachr, 2011).

Program postępowania $\mathrm{z}$ jednostką skazaną tworzy podstawę pedagogiki penitencjarnej. W gruncie rzeczy przedstawia aplikację składników wychowania do praktyki penitencjarnej, stosowanej w procesie resocjalizacji i reintegracji osoby więzionej (wychowanie rozumowe, etyczne, pracownicze, estetyczne i fizyczne). Do wspomnianych składników dokooptowane są: wychowanie prawnicze (celem kształtowania świadomości prawnej), ekonomiczne oraz enwironmentalne (ekologiczne), ewentualnie inne.

Podsumowując, można stwierdzić, że program postępowania ze skazanym stanowi teoretyczne wytyczne, dotyczące treści i metodyki specjalistycznych podejść, które w rezultacie prowadzą do próby reintegracji jednostki w społeczeństwie. Główną rolę odgrywają tutaj; praca społeczna, pedagogiczna i dokształcająca, wychowanie w duchu pracy, zajęcia w wolnym czasie, czynności duszpasterskie oraz kwestie stosunków międzyludzkich.

\section{Kompleksowa charakterystyka skazanego}

Celem opracowania z konkretnym skazanym adekwatnego, dobrego jakościowo programu, odpowiadającego jego osobowości, należy go możliwie najlepiej poznać. Służy do tego tak zwana kompleksowa charakterystyka skazanego, obejmująca poglądy i informacje, krótko mówiąc: całościową diagnostykę jednostki, którą zdobyto na podstawie obserwacji, anamnezy i przeprowadzonych rozmów. Umożliwia ona konkretne sformułowanie metod oddziaływania na więźnia. Do jej współtwórców należą następujące osoby:

- wychowawca w dziale kontaktów z osadzonym - kluczowy opiniodawca na temat skazanego z prostego powodu: codziennej styczności z nim;

- pracownik społeczny, skupiający się na uwarunkowaniach życiowych odbywającej karę jednostki (sytuacja rodzinna, dane o dzieciach, obowiązki alimentacyjne, zabezpieczenie finansowe itp.). Ustala również sytuację prawną danej osoby, zapewnia pomoc przy włączeniu się do życia społeczeństwa po zwolnieniu z zakładu karnego itp.;

- psycholog opracowuje diagnozę psychologiczną, analizuje rezultaty anamnezy oraz ich związek z czynnością przestępczą, bada osobowość z punktu wi- 
dzenia zdolności intelektualnych, stabilności emocjonalnej, orientacji na wartości, motywacji itp.;

- pedagog społeczny zajmuje się skazaną jednostką z punktu widzenia pedagogicznego i penitencjarnego, tj. osądza jego karierę kryminalną, mechanizm jej rozpoczęcia, motywację działania przestępczego itp. Ustala powiązania socjalne skazanego, zwłaszcza ze światem kryminalnym, rozpatruje agresywne zachowania, skłonności do reakcji ekstremalnych. Pedagog specjalny opiera swoją analizę na dotychczasowym stylu życia skazanego, jego stosunku do pracy, wykształcenia, zainteresowań. Ocenia jego zdolności i wartości moralne;

- lekarz (w większości przypadków więzienny) ustala ważne fakty zdrowotne dotyczące skazanego. Zaliczamy tutaj historię choroby, klasyfikację zdrowotną, diety, ograniczenia odnośnie zatrudnienia, wskazanie kuracji prewencyjnej itp. Do ważnych spraw należy ustalenie aktualnego stanu zdrowia skazanego, jego ewentualnego uzależnienia od używek, doświadczenia w tej dziedzinie;

- kapłan poznaje jednostkę z punktu widzenia wiary.

Do opinii o skazanym można włączyć również uwagi strażników, pielęgniarek, przełożonych w miejscu zatrudnienia, ewentualnie innych pracowników zakładu karnego i placówek współpracujących (Jůzl, 2012: 117).

\section{Programy postępowania - akływności skazanego}

Programy postępowania z więźniami, skupiające się na osobowościach skazanych jednostek, doprowadzają do najlepszych wyników w przypadku skoncentrowania się na specyficznych problemach powstających w związku $\mathrm{z}$ ich zachowaniem. Może przy tym chodzić o problemy, które nawarstwiły się podczas popełniania czynów karalnych albo wskutek doświadczeń podczas pobytu w zakładzie karnym. Spełniają one dwie funkcje:

- dają skazanym możliwość sprawdzenia, czy są w stanie podjąć konfrontację z poprzednimi i obecnymi problemami,

- stwarzają dla personelu więziennego większe pole do zrozumienia wzorcowych elementów zachowania skazanych.

\section{Akływności kształceniowe - wychowanie rozumowe}

Główny cel aktywności edukacyjnych stanowi pomoc jednostce w znalezieniu miejsca w społeczeństwie. Chodzi o różne formy dokształcania, polegające na ukończeniu szkoły podstawowej, zdobyciu wykształcenia zawodowego. Nauka or- 
ganizowana jest w szkolnych ośrodkach kształceniowych w wybranych zakładach karnych, w związku z tym nie wszyscy skazani mogą z niej korzystać.

Większość aktywności edukacyjnych realizowana jest za pośrednictwem programów postępowania ze skazanymi, zgodnie z ofertą i możliwościami danej placówki. Dokształcanie może przyjmować formę kursów, wykładów, działalności oświatowej itp. Chodzi m.in. o dostarczanie informacji z zakresu prawa, naukę języków obcych (angielski, niemiecki, hiszpański i inne), zapoznanie się z obsługą komputera, douczanie w zakresie języka ojczystego (ortografii, stylistyki, podstawowej wiedzy z dziedziny literatury rodzimej i światowej), nauczanie matematyki, wiedzy o społeczeństwie, historii. Szczyt aktywności kształceniowych stanowią studia wyższe, organizowane zgodnie z surowymi kryteriami w areszcie śledczym w Brnie (Jůzl, 2012).

\section{Specjalne metody pedagogiczne oraz udostępnianie wiedzy z zakresu etyki i religii}

Przez pojęcie „specjalne przedsięwzięcia wychowawcze” rozumiemy indywidualną i grupową opiekę pedagogiczną i psychologiczną. Zalicza się do niej różne rodzaje terapii, zwłaszcza arteterapię, ergoterapię i inne, w tym też specjalne ćwiczenia prowadzące do opanowywania własnej agresywności, doradztwo socjalno-prawne, doradztwo grupowe, rozmowy z psychologiem i pedagogiem specjalnym. Znaczący składnik stanowią także tzw. rozmowy odreagowujące (obniżające napięcie wewnętrzne), ewentualnie logoterapia. Do kluczowych osób w omawianej dziedzinie należy ksiądz, stosujący przy łagodnej „naprawie” jednostki patologicznej specyficzne metody, do których należy zwłaszcza dobre słowo, ofiarowane poprzez rozmowy duszpasterskie, doradztwo, cierpliwe wysłuchanie i objaśnienie powstałych problemów. Natomiast klasyczne metody pedagogiki specjalnej, kompensacja oraz rehabilitacja, uzupełniane są przez nowe podejścia pedagogiczne. Dalej stosowane są elementy wychowania rodzinnego i działalności duszpasterskiej. Można powiedzieć, że ksiądz, osoba niezależna, często łączy element religijny z funkcją psychologa, wychowawcy, pedagoga i pracownika społecznego. Jego moralne stanowisko i „ojcowskie podejście” jest niezastąpione w praktyce penitencjarnej (Jůzl, 2012).

\section{Wychowanie przez pracę}

Przytaczamy popularne słowa pioniera angielskiej nowoczesnej penitencjarystyki, Johna Howarda (1726-1790): „Pozwólcie więźniom pracować, a będą cnotliwi”. To 
poniekąd górnolotne stwierdzenie stanowi podstawę sensu jednej z głównych aktywności programu postępowania z więźniami - pracy. Wyrobienie nawyku pracy należy do najważniejszych warunków właściwej adaptacji społecznej i równocześnie antycypacji więźniów. $Z$ tych też powodów praca, stanowiąca element systemu postępowania $\mathrm{z}$ więźniami podczas całego okresu odbywania kary pozbawienia wolności, była znaczącym elementem resocjalizacji zarówno w przeszłości, jak i obecnie.

Ustawa o odbywaniu kary pozbawienia wolności wręcz zobowiązuje skazanego do pracy, o ile zajdzie taka potrzeba. Europejskie zasady więziennictwa uważają pracę skazanych za najważniejszy czynnik społeczny oraz integracyjny. Brak zajęć u więźniów stanowi natomiast jedno $\mathrm{z}$ największych zagrożeń możliwego niepowodzenia reintegracyjnego. W Republice Czeskiej pracuje około 60\% skazanych.

Czynności pracownicze można podzielić następująco:

- prace potrzebne do zapewniania funkcjonowania zakładu karnego;

- praca i zatrudnienie $\mathrm{w}$ zakładach produkcyjnych i innych przedsiębiorstwach;

- praca w ośrodku działalności gospodarczej w danym zakładzie karnym;

- praca jako aktywność terapeutyczna prowadzona przez fachowych pracowników służby więziennej, w ramach której wykonywane są roboty w kuchni, w ogrodzie, przy sprzątaniu itp. (Jůzl, 2012).

\section{Obszary tworzenia się związków wewnętrznych}

Celem jest wzmacnianie i pielęgnowanie więzi z rodziną i osobami bliskimi, co sprzyja zaspokajaniu podstawowych potrzeb psychicznych skazanych, jak również potrzeby kontaktu ze światem zewnętrznym (urzędami, PMS - Urząd Nadzoru i Mediacji, kuratorami itp.). Ta część programu postępowania bywa określana również jako ekstramuralna. Głównym organizatorem jest tu pracownik socjalny oraz osoba duchowna.

\section{Spędzanie czasu wolnego (zainteresowania)}

Aktywne spędzanie czasu wolnego stanowi ważny element programu postępowania $\mathrm{z}$ więźniami. Często zdarza się, że nie można zapewnić skazanym pracy, będącej zasadniczym elementem programu. Aktywności w czasie wolnym należy podzielić z jednej strony z punktu widzenia wychowania estetycznego, z drugiej zaś - wychowania fizycznego. Ich sens polega na nauczeniu, jak należy efektywnie spędzać czas wolny, by potem po opuszczeniu zakładu karnego wprowadzić pozytywne zmiany w swoim trybie życia. Aktywności te sprzyjają również utrzymaniu dobrej kondycji psychicznej i fizycznej więźnia, obniżając jego napięcie, będące 
skutkiem pryzonizacji. Chodzi o zaspokajanie zainteresowań, realizację własnych hobby i upodobań skazanych, do czego mają oni niekwestionowane prawo i co jest mile widziane w praktyce penitencjarnej.

Zajęcia w ramach wolnego czasu, mające charakter wychowania estetycznego, mogą występować w ogromnej różnorodności dlatego wymienianie ich wszystkich nie miałoby sensu. Podobnie wygląda sprawa $\mathrm{z}$ aktywnościami fizycznymi i sportowymi - jak mówią wyniki ankiety.

Jako pozytywne zjawisko można potraktować czynny udział jednostki w wytwarzaniu wartości kulturowych oraz w kreowaniu działań z zakresu wychowania estetycznego: polega to na uczestniczeniu w pracach najróżniejszych kół zainteresowań - rzeźbiarskich, modelarskich, instrumentalnych, śpiewaczych, czytelniczych, plastycznych; poza tym w kółkach krawieckich, zajmujących się wyszywaniem, szydełkowaniem, robótkami na drutach, pracami w drewnie, kamieniu, kowalstwem, kółkach zrzeszających hodowców (na przykład rybek akwariowych), miłośników upraw (rośliny pokojowe i ogrodowe), ceramicznych.

Wychowawca i inni pracownicy więziennictwa, wykorzystując własną wiedzę i umiejętności, kierują aktywnościami uczestników, udzielają im rad, ewentualnie włączają do samodzielnego prowadzenia kół zainteresowań. Aktywności jest bardzo dużo, wystarczy tylko uruchomić wyobraźnię i wykorzystać zdolności, a niekiedy wręcz talent twórczy osadzonych w zakładzie karnym. Z punktu widzenia motywacji niezmiernie korzystne jest organizowanie wystaw prac więźniów czy konkursów. Można też ozdobić ich produktami świetlice, korytarze itp. Nasilenie aktywności ma miejsce w okresach okołoświątecznych (Boże Narodzenie, Wielkanoc). Poza udziałem w licznych kółkach zainteresowań warto wspomnieć także o ulubionych zajęciach, takich jak tenis stołowy, gra w karty, rozwiązywanie krzyżówek.

Strona receptywna obejmuje oglądanie programów telewizyjnych, wideo, słuchanie radia, jak również uczestniczenie jako widz w występach zespołów muzycznych i aktorów na żywo, ewentualnie w sztukach teatralnych w wykonaniu więźniów. Chodzi o to, że nawet skazany, który nie bierze bezpośredniego udziału w tworzeniu wartości natury estetycznej czy naukowej, może być mocno zaangażowany uczuciowo w odbieranie prezentowanych treści, dlatego nie powinno się tu mówić o „stronie pasywnej”.

W związku z działaniami w sferze wychowania estetycznego do aktywności związanych ze spędzaniem wolnego czasu przenikają pierwiastki nowego podejścia: resocjalizacji twórczej, której podstawę stanowi odkrycie i wykorzystanie wszystkich zdolności twórczych jednostki oraz ich rozwój - w odróżnieniu od klasycznych metod etopedycznych (metoda teatru resocjalizacyjnego, metoda resocjalizacji za pomocą sportu, dramatoterapia - utwory własne bądź stworzone przez kogoś innego, muzykoterapia - gra na instrumencie, śpiew, występy, działalność twórcza - malarstwo, rysunek, modelarstwo, psychodrama i socjodrama). (Jůzl, 2012). 


\section{Akływności z dziedziny sportu i kultury fizycznej}

Również tutaj istnieje cała masa zajęć. Ten typ aktywności jest bardzo mile widziany w więziennictwie na całym świecie, co wyraźnie widać w wielu filmach zagranicznych, zwłaszcza amerykańskich. Za punkt wyjścia bierze się tu kilka czynników, które sprzyjają inhibicji niepożądanej agresji, nudy bądź też knowań niektórych więźniów. Z ćwiczeń oferowanych przez więzienie ogromnym powodzeniem cieszą się zajęcia kondycyjne na siłowniach, gra w ping-ponga, piłkarzyki itd. Na przestrzeniach otwartych i wszędzie, gdzie jest to możliwe, zwłaszcza na boisku, uprawia się grę w piłkę nożną, siatkową, koszykówkę, tenis stołowy itp. Nie mają racji bytu stwierdzenia, jakoby w siłowniach więźniowie „wyrabiali mięśnie” do walki ze strażnikami; przede wszystkim bowiem należy mieć na względzie tłumienie nadmiaru ich energii.

Również służby więzienne starają się realizować cel wychowania fizycznego, w wyniku którego więzień staje się jednostką dobrze rozwiniętą ruchowo, rozumiejącą, że aktywność sportowa jest niezbędnym elementem jej stylu życia. Dlatego służby te wspierają działalność sportową i dotyczącą wychowania fizycznego przez organizowanie dłuższych, a także krótkich zawodów (dobrze jest znowu połączyć je z jakimś uroczystym wydarzeniem i nagrodzić zwycięzców). Do najpopularniejszych turniejów należą: gra w szachy, w ping-ponga i cały szereg innych, w zależności od zainteresowań osadzonych, jak również wychowawców. Jedną z form są mecze między więźniami i dozorcami.

Tak jak w przypadku aktywności $\mathrm{z}$ wychowania estetycznego, w zajęciach sportowych rozróżniamy stronę aktywną (jednostka sama przeprowadza własne ćwiczenia) i stronę receptywną, zwłaszcza przy oglądaniu sprawozdań sportowych w telewizji. W przypadku więźniów młodocianych ma miejsce szczególnie silne wspieranie aktywności w ramach czasu wolnego. Program minimalny jest realizowany u tych skazanych, którzy nie wybrali żadnej z proponowanych przez więzienie alternatyw programowych. Składa się on z zajęć najbardziej podstawowych, kierowanych od strony pedagogicznej i organizacyjnej przez pracowników więzienia. Osobą odpowiedzialną jest pedagog specjalny.

\section{Prawa skazanych}

Celem tej rozprawy nie jest wymienianie ani analizowanie wszystkich praw osób przebywających w zakładzie karnym, dlatego przypomnimy tylko te najbardziej podstawowe, wywodzące się z ustawy o karze pozbawienia wolności, którą oferujemy czytelnikom do konfrontacji z przedstawionymi programami postępowania Z więźniami. Stanowią one podstawę humanizacji więziennictwa. Do najważniej- 
szych praw należą: równość skazanych wobec prawa odnośnie warunków socjalnych i zdrowotnych (jak na przykład własne łóżko, ośmiogodzinny nieprzerwany sen, higiena, trzy posiłki dziennie, wyjścia na powietrze, czas wolny dla siebie itp.), prawo do korespondencji i używania telefonu, odwiedzin, posług religijnych i społecznych, zaspokajania potrzeb kulturalnych, używania rzeczy innych niż własne (na przykład wypożyczanie książek, gier towarzyskich itp.), zakupu artykułów żywnościowych i rzeczy osobistych, otrzymywania paczek (2 razy na rok), zarabiania pieniędzy i wydawania ich. Prawa więźniów podlegają ochronie łącznie ze środkami ochrony prawnej.

Ponieważ jednak wciąż mamy do czynienia ze skazanym, a kara musi pozostać karą, dochodzi do pewnych ograniczeń niektórych praw i swobód, jeżeli ich przyznanie stałoby w sprzeczności z celem wykonywania kary pozbawienia wolności lub jeżeli nie można ich zagwarantować ze względu na rodzaj kary (ustawa o wykonywaniu kary pozbawienia wolności nr 169/1999 Dz.U.).

\section{Podstawowe obowiq̨zki osadzonych}

Skazany podczas odbywania kary pozbawienia wolności ma obowiązek przestrzegania ustanowionego regulaminu oraz dyscypliny, jak również wykonywania zaleceń i nakazów pracowników służby więziennej. Powinien też pracować, o ile przydzielono mu pracę, a on nie został uznany za niezdolnego do jej wykonywania czasowo lub na cały okres odbywania kary, wypełniać zadania wynikające z programu postępowania $\mathrm{z}$ więźniem, dbać o powierzone mu przedmioty, nie niszczyć cudzego majątku, przestrzegać zasad utrzymywania poprawnych stosunków z otaczającymi go osobami oraz respektować wewnętrzny regulamin placówki penitencjarnej. Powinien też przestrzegać nakazów wynikających ze szczególnych przepisów prawnych, odnoszących się do zapewnienia bezpieczeństwa i ochrony zdrowia w czasie pracy, jak również ochrony przeciwpożarowej.

Więzień ma obowiązek także:

1) poddawać się kontrolom osobistym, jeżeli zapewni to utrzymanie porządku wewnętrznego w zakładzie oraz wykluczy możliwość posiadania przy sobie przedmiotów, które przekreślałyby sens odbywania kary pozbawienia wolności;

2) umożliwiać pracownikom służby więziennej kontrolę swoich rzeczy osobistych;

3) poddawać się lekarskim badaniom profilaktycznym - wstępnym, okresowym, specjalistycznym oraz końcowym (przed wyjściem na wolność) w terminach wyznaczonych przez lekarza bądź specjalne przepisy prawne, łącznie z niezbędnymi badaniami diagnostycznymi, laboratoryjnymi, szczepieniami oraz zabiegami zalecanymi przez służby higieniczne; 
4) zgadzać się na czynności, które mają związek z jego identyfikacją oraz poddać się zabiegom niezbędnym dla opracowania kompleksowego sprawozdania;

5) w przypadku zachorowania, doznania urazu lub zranienia, musi natychmiast zgłosić ten fakt pracownikowi służby więziennej;

6) natychmiast powiadomić pracownika służby więziennej o okolicznościach, które mogą stanowić poważne zagrożenie bezpieczeństwa jego samego, współwięźniów, a nawet całego zakładu karnego, kiedy tylko się o nich dowie lub je zbada;

7) poddać się badaniom, niezbędnym do zapobiegania wytwarzaniu, posiadaniu bądź używaniu środków halucynogennych i psychotropowych oraz toksycznych na terenie więzienia;

8) przestrzegać zasad higieny;

9) bezzwłocznie poinformować odnośne władze, że pobiera emeryturę, dodatek za wysługę lat, dodatek za służbę, bądź też osiąga dochody podlegające opodatkowaniu;

10) przekazać do depozytu rzeczy, których posiadanie ze względu na ich wartość, ilość lub sposób stosowania jest zakazane lub stoi w sprzeczności z sensem odbywania kary pozbawienia wolności;

11) pokrywać koszty usług medycznych świadczonych celem poprawy jego stanu zdrowia i wykraczających poza ramy zabiegów finansowanych z Narodowego Funduszu Zdrowia bądź przez Zakład Ubezpieczeń Społecznych oraz przekraczających wartości uwzględnione w umowach międzynarodowych, wiążących dla Republiki Czeskiej (Ustawa o wykonywaniu kary pozbawienia wolności nr 169/1999 Dz.U.).

Więźniom zabrania się:

1) nawiązywania kontaktów $z$ innymi osobami, jeżeli jest to niezgodne $z$ niniejszą ustawą lub z zarządzeniem wydanym na podstawie tejże ustawy;

2) wyrobu, przechowywania i konsumowania napojów alkoholowych oraz innych środków uzależniających, wyrobu i przechowywania przedmiotów, które mogą być użyte do spowodowania zagrożenia bezpieczeństwa osób i majątku bądź też do ucieczki, ewentualnie które ze względu na swoją ilość i rodzaj mogłyby zakłócać porządek lub szkodzić zdrowiu;

3) przechowywania i rozpowszechniania publikacji propagujących nienawiść narodową, etniczną, rasową, religijną, lub społeczną, faszyzm i inne podobne ruchy, zmierzające do ograniczenia praw i wolności człowieka, gloryfikujących przemoc i brutalność, jak również publikacji i materiałów zawierających instrukcje wyrobu i stosowania środków uzależniających, toksycznych, materiałów wybuchowych, broni i materiałów palnych;

4) gry o pieniądze, rzeczy, usługi lub inne świadczenia; brania udziału w loteriach i podobnych grach; 
5) tatuowania ciała własnego lub innych osób bądź poddawania się temu zabiegowi;

6) symulowania utraty zdrowia lub umyślne samookaleczenia;

7) sprzedaży, ofiarowywania lub wymiany rzeczy posiadanych w zakładzie karnym bez zgody służb więziennych.

Wobec osadzonego, który bez powodu odmawia wypełniania obowiązków, przy czym nie reaguje na zwracanie uwagi tudzież napomnienia, służby więzienne użyją środków przewidzianych ustawą w stosownym wymiarze (Ustawa o wykonywaniu kary pozbawienia wolności nr 169/1999 Dz.U.).

\section{Badania ankietowe}

Ukierunkowane na przestrzeganie praw i obowiązków osób odbywających karę pozbawienia wolności badania odbyły się w trzech dużych więzieniach na terenie Republiki Czeskiej. Brało w nich udział łącznie 127 respondentów. Opracowana ankieta miała charakter pilotażowy i składała się z ośmiu prostych pytań. Uczestnicy zostali wybrani losowo spośród więźniów. Głównym zadaniem badania było stwierdzenie, czy są przestrzegane prawa i obowiązki osadzonych wynikające z ustawy nr 169/1999 Dz.U.

\section{Analiza i interpretacja wyników badań}

\section{Pytanie 1: Czy zna Pan/Pani swoje prawa jako więźnia?}

Z liczby 127 skazanych twierdząco odpowiedziało 107 osób, 9 uznało, że nie zna, zaś 11 nie było zdecydowanych. Wynika z tego, że służby więzienne w Republice Czeskiej dbają o zapoznanie skazanych z ich prawami.

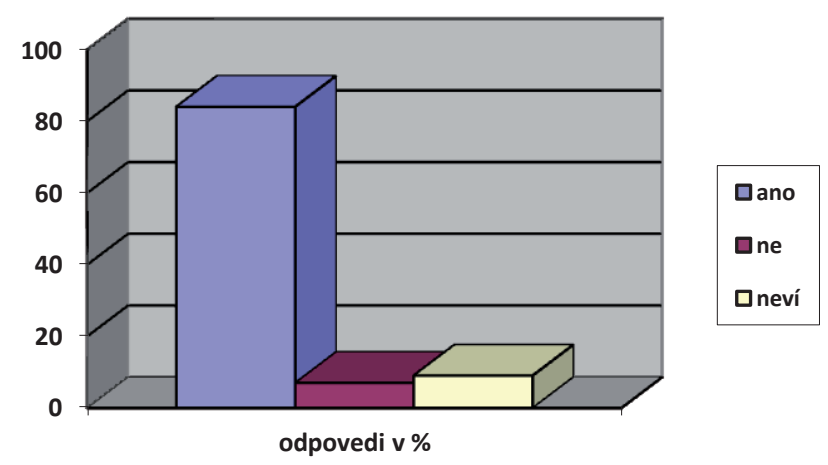

Legenda: ano - tak, ne - nie, neví - nie wie 


\section{Pytanie 2: Czy stosuje je Pan/Pani w praktyce?}

Na to pytanie twierdząco odpowiedziało 87 skazanych, 20 nie korzysta ze swoich praw w praktyce, zaś 20 nie zajmuje się tym problemem. Pytanie to jest ściśle związane z poprzednim, ponieważ tylko ten, kto zna swoje prawa, może je w pełni egzekwować.

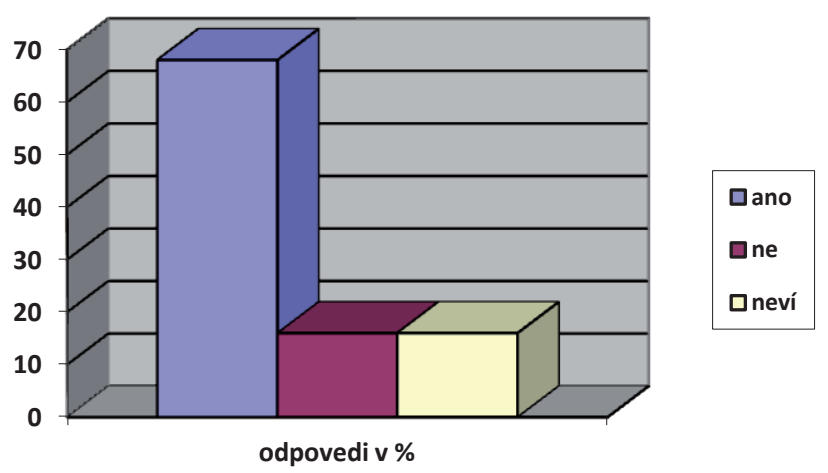

\section{Pytanie 3: Czy służby więzienne przestrzegają praw skazanych?}

84 respondentów uważa, że prawa więźniów są przestrzegane, 22 jest zdania, że w żadnym wypadku, natomiast 21 badanych nie wie. Znowu potwierdza się doskonałe poinformowanie więźniów o ich prawach z jednej strony, zaś z drugiej - maksymalne starania służb więziennych, by praw tych przestrzegać.

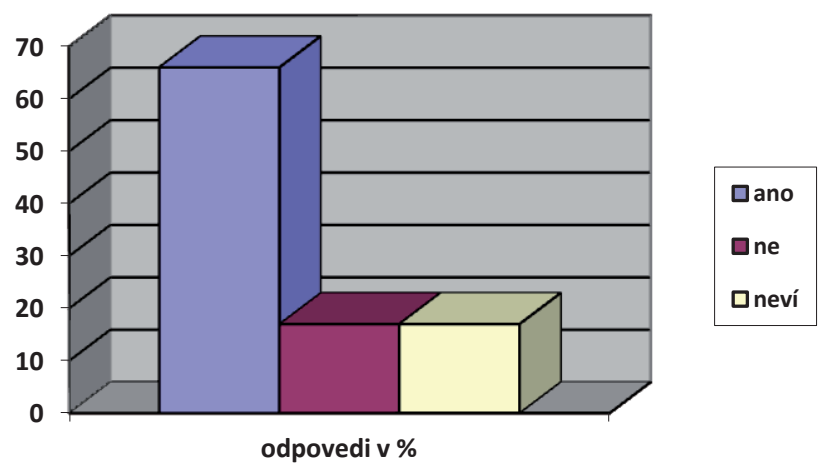

Pytanie 4: Czy zna Pan/Pani obowiązki więźnia?

Z ogólnej liczby 127 respondentów 122 odpowiedziało TAK. Dowodzi to, że służby więzienne bardzo starannie przygotowują więźniów pod kątem ich obowiązków. 


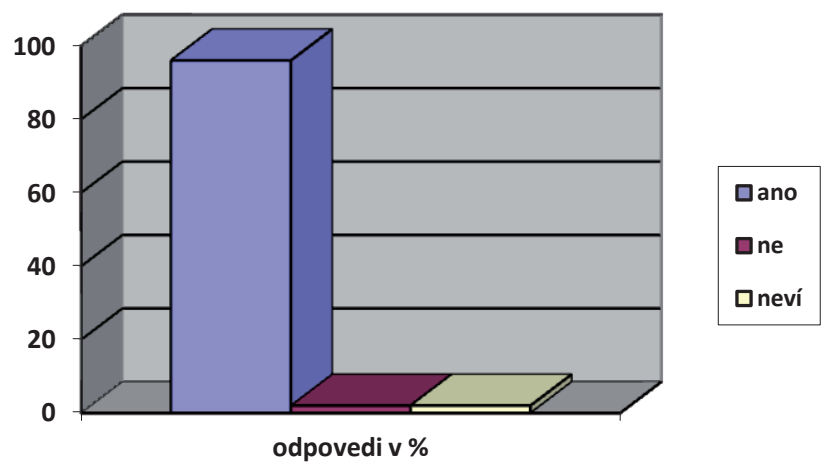

Pytanie 5: Czy wypełnia Pan/Pani swoje obowiązki?

117 odpowiedzi twierdzących, chociaż z komentarzem - że „po prostu muszę". 3 respondentów odpowiedziało NIE, ale zdają sobie sprawę ze skutków swojego postępowania. 7 więźniów wyraziło się w sposób neutralny. Wykonywanie obowiązków skazanego na karę pozbawienia wolności wypływa przecież z ustawy, którą należy przestrzegać.

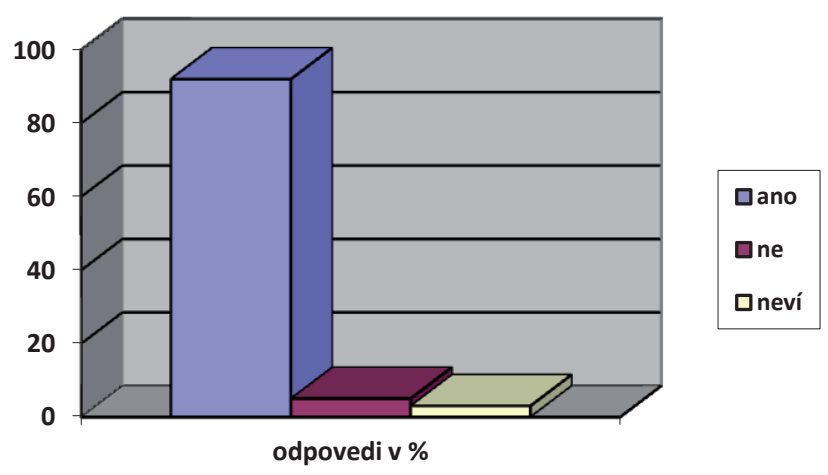

\section{Pytanie 6: Czy są one egzekwowane przez służby więzienne?}

Egzekwowanie wypełniania obowiązków przez więźniów to najważniejsza sprawa w pracy służb więziennych. Nic dziwnego więc, że aż 114 respondentów przyznało, że wypełnianie przez nich obowiązków jest konsekwentnie egzekwowane, 5 stwierdziło, że nigdy, a 8 nie było pewnych. 


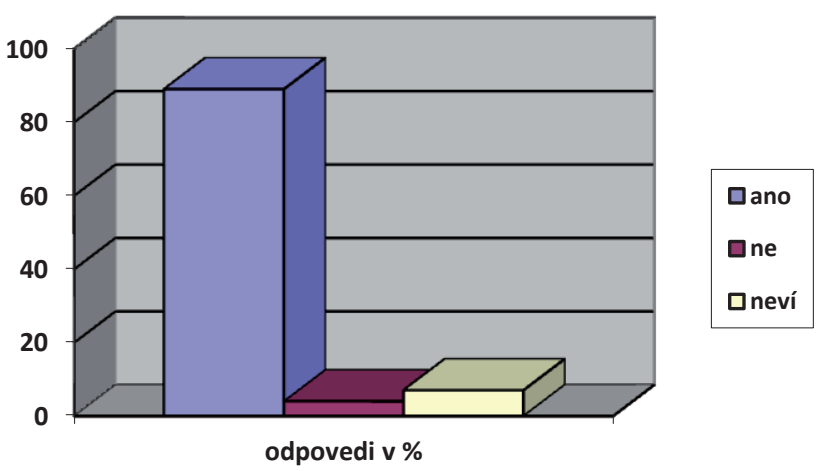

Pytanie 7: Co proponuje Pan/Pani, by zwiększyć prawa skazanego?

$50 \%$ więźniów stwierdziło z rezygnacją, że nic. Niektórzy jednak zgłosili propozycje, mogące być bodźcem dla służb więziennych. Najczęściej chodziło o legalizację tzw. wizyt niestandardowych (intymnych), zapewnienie pracy dla każdego więźnia, poprawę warunków higienicznych, kulturalniejsze i grzeczniejsze traktowanie ich przez strażników. Do mniej ważnych postulatów zaliczyć można: zwiększenie ilości paczek (ponad 2 w roku), prośba o amnestię, wyjścia na łono natury, większe możliwości realizowania swoich zainteresowań, osadzanie w zakładzie możliwie najbliżej miejsca zamieszkania, lepsze zaopatrzenie kantyny, większe szanse na kształcenie się, możliwość kupowania obiadów poza więzieniem, zezwolenie na częstsze połączenia telefoniczne itp.

Pytanie 8: Co, zdaniem Pana/Pani, należałoby dodać do obowiązków skazanego?

Najczęstszą odpowiedzią było rzecz jasna „NIC, i tak mamy ich dużo”. Jedynie nieliczni domagali się obowiązku pracy, co przecież jest ujęte w ustawie, oraz postępowania zgodnie $\mathrm{z}$ zasadami więziennictwa europejskiego, co również jest przestrzegane.

\section{Wniosek końcowy}

Analizując osiągnięte wskaźniki, służby więzienne Republiki Czeskiej mogą być zadowolone z wyników. Skazani znają swoje prawa i obowiązki. W razie potrzeby potrafią domagać się ich przestrzegania drogą oficjalną. Ciążące na nich obowiązki, wynikające z ustawy o wykonywaniu kary pozbawienia wolności, starają się wypełniać, bowiem mają ku temu motywację. 


\section{Zakończenie}

\section{Przecież nie jest im tak źle w tym więzieniu!}

Programy postępowania $\mathrm{z}$ osobami skazanymi na karę pozbawienia wolności są podstawą pedagogiki penitencjarnej oraz penitencjarystyki, jak również ich humanizacji. Opierają się one na teorii wychowania i aplikacji poszczególnych elementów wychowania do praktyki penitencjarnej. Ich efektywność zależy od motywacji, profesjonalnego podejścia personelu więziennego oraz chęci skazanych do współpracy. Mierzy się ją za pomocą analizy wskaźnika powrotu skazanych do kolejnej kary. Dawniej wynosił on tylko 20\%. Dzisiaj, przy innym składzie więźniów (cudzoziemcy), charakterze czynów przestępczych itp., zastosowanie w więziennictwie zasad europejskich oraz umów międzynarodowych ten wskaźnik rośnie, choć nie jest on badany przez statystykę. Z pewnością badanie takie miałoby korzystny wpływ na praktyki penitencjarne. Programy postępowania z więźniami wywodzą się z praw i obowiązków więźnia. Nakładają się one (wraz z regulaminem) na wszelkie dziedziny życia jednostki za kratami. Dlatego tak bardzo ważne jest $\mathrm{z}$ jednej strony przestrzeganie prawa skazanego, z drugiej zaś egzekwowanie jego obowiązków. Tylko w ten sposób zostaną zrealizowane cele resocjalizacyjne.

Przy wszelkich optymistycznych spojrzeniach na stan czeskiego więziennictwa należy ciągle pamiętać raport Woolfa, który może być receptą na rozwiązywanie problemów penitencjarnych nie tylko w Republice Czeskiej, ale także w innych krajach Europy.

\section{Literatura}

Evropská vězeňská pravidla, poslední aktualizované vydání, 2006.

Foucault M. (2000). Dohližet a trestat. Praha.

Inciardi J.A. (1994). Trestní spravedlnost. Praha

Jůzl M. (2012). Penitenciaristika a penologie. Brno

Mühlpachr, P. a kol. (2011). Sociální pedagogika II. Brno.

Sochůrek J. (2007). Kapitoly z penologie II. Liberec.

Woolfova zpráva. (1996). Př́loha časopisu „České vězeňstvi“ č. 2.

Zákon č. 169/1999 Sb. 


\section{Treatment Programs as a Platform for Social Rehabilitation and Respecting the Rights of Prisoners}

\section{Summary}

Miloslav Jüzl in the article Treatment Programs as a Platform for Social Rehabilitation and Respecting the Rights of Prisoners sets for himself the goal to present and explain the essence of rehabilitation of people imprisoned basing on the programs of conduct with prisoners, including the ongoing humanization of the Czech penitentiary system in the context of respecting the rights and duties of prisoners.

As a specific matrix of conduct with prisoners the author recalls conclusions from a report on the state of British penitentiary system from early 1990's prepared by a member of the Highest Court of Great Britain judge Woolf (the so called Woolf Report) in response to long term problems occurring in England's penitentiary facilities.

Author describes the aims, tasks and rules for being imprisoned, stressing out that "effectiveness of the punishment supports maintaining the law and order, humanization, deprisonization, democratic approach". In this context the author distinguishes the term creative rehabilitation, which in contrast to common rehabilitation understood as a process of renewed socialization dealing with correcting the social and individual potentials of a person, develops the human potential. Social maladjustment is being treated as a deficit socialization of identity and not just as a deviatory position of a self.

Programs of conduct with imprisoned people are, according to the author, the basis for penitentiary pedagogy and as well its humanization. They are based on the theory of upbringing and the application of selected elements of upbringing into the penitentiary praxis. Their effectiveness depends on motivation, professional approach of the prison's personnel and the will of inmates to cooperate. The programs of conduct with imprisoned people derive from inmate's rights and duties. That's why it is so important on one hand to comply with the inmate's rights and on the other to execute their duties. This is the only way to realize the aims of rehabilitation.

In a further part of the article author presents the outcome of a survey research, focused on maintaining the rights and duties of people serving their time in prisons conducted in three large penitentiary facilities located in the Czech Republic. The survey included a research sample consisting of 127 people. The survey was an initial study and consisted out of eight simple questions. People interviewed had been selected randomly among inmates. The main task of the research was to assert if the rights and duties related to the Legal Act No. 169/1999 of the Czech Republic were maintained.

When analyzing the results of the research author claims in the conclusion that "the penitentiary services of the Czech Republic may be delighted with the outcome. Inmates are aware of their rights and duties. In case, they might demand their maintaining through official paths. They attempt to fulfill their duties lying upon them in relation to the legal act on imprisonment because they are motivated to do so". 
